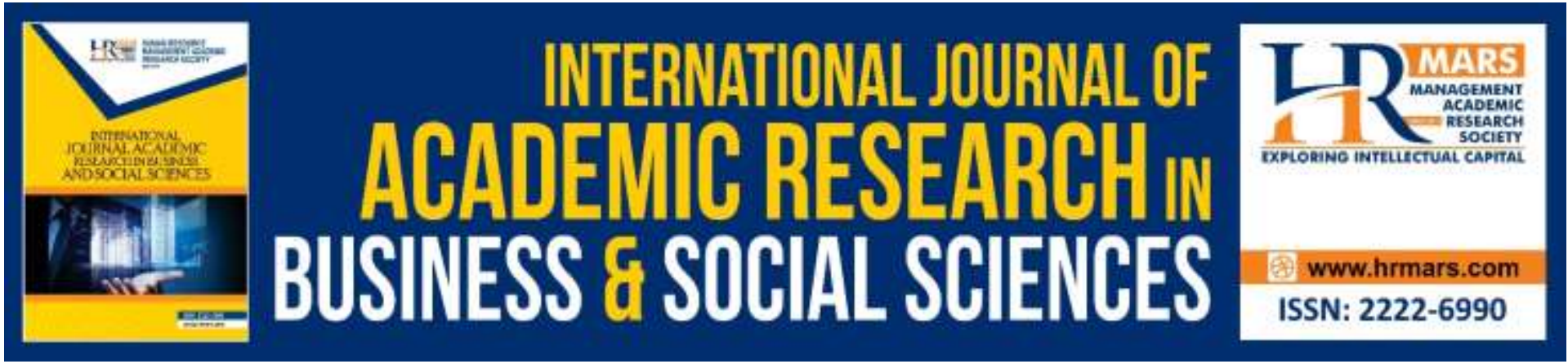

\title{
An Analysis on the External Factors of Malaysian Women's Involvement in Extremism Group
}

Muhd Imran Abd Razak, Mohd Anuar Ramli, Mohd Farhan Abd Rahman, Ahmad Firdaus Mohd Noor, Nurul Khairiah Khalid, Mukhamad Khafiz Abd Basir

To Link this Article: http://dx.doi.org/10.6007/IJARBSS/v9-i9/6316

DOI:10.6007/IJARBSS/v9-i9/6316

Received: 09 July 2019, Revised: 17 August 2019, Accepted: 06 September 2019

Published Online: 28 September 2019

In-Text Citation: (Razak, Rahman, Noor, Khalid, \& Basir, 2019)

To Cite this Article: Razak, M. I. A., Rahman, M. F. A., Noor, A. F. M., Khalid, N., \& Basir, M. A. R. K. K. A. (2019). An Analysis on The External Factors of Malaysian Women's Involvement in Extremism Group. International Journal of Academic Research in Business and Social Sciences, 9(9), 479-486.

\section{Copyright: (C) 2019 The Author(s)}

Published by Human Resource Management Academic Research Society (www.hrmars.com)

This article is published under the Creative Commons Attribution (CC BY 4.0) license. Anyone may reproduce, distribute, translate and create derivative works of this article (for both commercial and non-commercial purposes), subject to full attribution to the original publication and authors. The full terms of this license may be seen at: http://creativecommons.org/licences/by/4.0/legalcode

Vol. 9, No. 9, 2019, Pg. 479 - 486

Full Terms \& Conditions of access and use can be found at http://hrmars.com/index.php/pages/detail/publication-ethics 


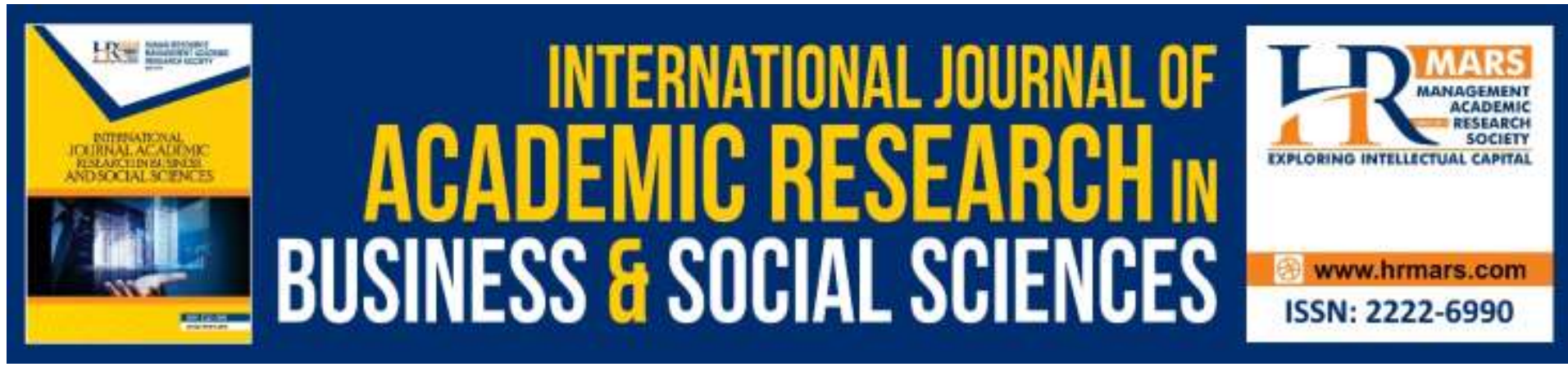

\title{
An Analysis on The External Factors of Malaysian Women's Involvement in Extremism Group
}

\author{
Muhd Imran Abd Razak (PhD) \\ Universiti Teknologi Mara
}

\author{
Mohd Anuar Ramli (PhD) \\ Universiti Malaya
}

\section{Mohd Farhan Abd Rahman, Ahmad Firdaus Mohd Noor (PhD), Nurul Khairiah Khalid, Mukhamad Khafiz Abd Basir Universiti Teknologi Mara}

\begin{abstract}
The development of religious extremism is driven by various internal and external factors. In addition, it also involves women either as fighters or victims of war. In this regard, this study discusses the external factors of women's involvement in groups of religious extremists, particularly in Daesh group. In order to achieve the objective, this qualitative study was conducted through library approach and interviews with the deradicalization experts, case witnesses and police authorities. The data collected were analysed inductively showing that women's involvement in religious extremism is driven by a variety of external factors, including; deceived by sweet promises such as heavenly rewards and a marriage to the male fighter. They were easily exploited and manipulated by the male fighters too. Therefore, authorities need to take critical actions to restrain the involvement of women and men in this movement.
\end{abstract}

Keywords: Religious Extremism, Women Fighters, Gender Stereotypes, Jihad, Security

\section{Introduction}

As of July $16^{\text {th }}, 2018$, the statistics pertaining to the capture of women involved in the group of extremism by the Royal Malaysia Police (PDRM) has shown the number of 43 . In Syria alone, 53 Malaysians have become the members of the Daesh group, including 12 women (PDRM, 2018). Although the involvement of women in this group could be considered as low, the expansion of women's role in group of extremism must be taken seriously (Khan, 2018). For example, the detention of a 51-year-old woman was believed to have planned an attack on Chinese voters on the day of the $14^{\text {th }}$ General Election. She, who was also the 
Daesh group cell leader, was also involved in recruiting new members of women and men via Facebook and WhatsApp (Khan, 2018; Hanis, 2018). It shows that by neglecting the future of what these women might become will put the country at high risk. Hence, the pattern of behaviour of these women, especially the Malaysians, should be observed and analysed to guarantee the effectiveness of the counter terrorism method to be effectively implemented. To date, many international studies have been conducted on the factors of women's involvement in extremist groups, but no studies have been done specifically on the factors of Malaysian women's involvement. Therefore, this study focuses on the external factors of Malaysian women's involvement in the Daesh group.

\section{Literature Review}

In general, researchers of religious extremism have neglected the importance of differentiating the factors related to the involvement, between men and women, in religious of extremism, unless for some specific factors. However, Awan (2007) and Rahimullah (2013) see it as the unity of Muslims as an ummah (the spirit of brotherhood), which extends beyond the boundaries of nation, race and gender. For example, in the war events such as in Bosnia, Chechnya, Afghanistan, and the latest, in Iraq and the Middle East, the feeling of empathy among Muslims around the world bring together great influence for them to respond. Moreover, the feeling of being discriminated in the Western world has created anti-Western sentiment among Muslims, which is seen by Awan (2009) as an important factor in spreading radicalism among Muslims. In his research, McCauley (2011) also found that the American Muslim soldiers were having dilemma to fight the al-Qaeda groups in the Middle East because they thought they were fighting Islam.

Furthermore, the increasing phenomena of racism and Islamophobia in the West are seen as the major contributing factors. Beutal in his study (2007) found that the disproportion of treatment towards the Muslim by the Western locals, especially in the United State, has led to a high risk of extremism, developed through hatred. The study conducted by Kabir (2007) in Australia further explains the fact. According to him, following the incident of September 11, 2001, Muslim women in Australia were banned from wearing their traditional Islamic dress, and they were both verbally and physically assaulted. Two mosques were attacked and totally burned in Brisbane, Queensland. Dunn et al. (2011) also shows similar findings. His study found that between 1999 and 2011, racism or antiIslamism among Australians has increased to $48.6 \%$.

Other than that, another factor involving a person in extremism is because of social networks. The results of the study conducted by Bakker (2006), later by Veldhuis and Staun (2009) found that terrorists in Europe were consisted of those who had the same background in terms of demography such as ethnicity, age, place, neighbourhood and recruitment methods. Similarly, the study by Sapurto (2010) on the probability of a terrorist group using women as a suicide bomber in Indonesia found that the family and social relationships with terrorists could be the reason for the action to take place. This research is supported through the finding of McPherson (2001) in his study which presented the theory of equality of social networking methods to create the same personal traits and beliefs. 
In addition, one of the factors which is seen to be significant in the development of ideology of religious extremism is the role of the internet as a media. In fact, researches on the role of internet are largely and extensively done. In the early stages, as Veldhuis and Staun (2009) explained, internet has become an influential medium because it is an easy medium to spread a propaganda and an easy way to reach its target. However, there are also researchers who see the internet as less important to develop the ideology of extremism. For example, Stevens and Neumann (2009) believe that the internet in 2009 still played a minimum role by terrorists to spread ideology and attracted world community support. Perhaps because the situation has changed, current studies have shown otherwise.

Specifically highlighting the involvement of women in the Daesh group, Ali (2015) found that the major factors of the women's participation in the Daesh group were due to the influence of false promises related to living a beautiful life with the fighters either as a wife or as an assistant to the fighter. Rafiq and Malik (2015) further clarify that the Daesh group deceived women through the medium of propaganda by offering four major deals, which are; living a happy life beside the fighters, free from the oppressive world, active involvement behind the scene and reach to the status of taqwa in religion. Kneip (2016) in her study tries to identify the cause of women's involvement in militant movements because the members in the Daesh group from Western countries is so high and constantly increasing. She believed that women's personal problem has contributed to this increasing number of recruitments. Women are so intense with their conservative family (parents or husband) who are less likely open to freedom of expression or action,), discriminated by the locals at the place living, and the pride as well as become highly motivated to be part of a brave warrior.

\section{Methodology}

The researchers have conducted two stages of study. First, analysis of documents including books, theses, journals, papers and the collections of the Dabiq magazine of the Daesh group to understand the background, the problems and build the framework of research objective. Second, the interview method was applied to selected informants which aimed to classify certain codes as important themes based on the answers obtained from the interview. The interview method was used to obtain data related to the information or phenomenon that was not observed directly such as attitude, beliefs, views, experiences and interests. It also saught to obtain more in-depth information to elaborate and support the data obtained through the library method used by the researcher as the main method (Piaw, 2011). Furthermore, researchers used this method to gain information about the reality of the involvement of women in religious extremist groups, important information connecting them through the deradicalization process carried out by the authorities and the justification of the law according to the perspective of experts in Islamic law. In order to achieve this objective, the semi structural interview method was used to obtain information directly from informants. This method is important because the data and the information obtained would be fair, up to date and more accurate than those directly involved in the problems studied. The interview technique is also flexible and this allows the informant to be open with his views. In this study, the researcher has chosen several individuals as informants who were identified as having a significant background with the theme of the 
study and have agreed to be interviewed. The data from these two stages were then analysed together with content and thematic analysis to answer the research problem.

\section{Result and Discussion}

The researcher found that the factors involving Malaysian women in the extremist groups can be divided into internal and external factors. The internal factors refer to the cause of the extreme ideology inherited by the individual himself such as ignorant, obsessed, jumūd and stringent. While external factors refer to external elements that influence general practices of extremism - political, social, economic, mass media and marital influences or romance relationship. These factors are linked to one another. However, this article is intended to discuss only on the external factors of Malaysian women's involvement.

\section{Local and International Politics}

The researchers found that at least four political and geopolitical aspects were identified contributing to the signs of female extremism in Malaysia. First, the discrimination of the Islamic government against their own people. Second, the occupation or imperialism of the Western powers over Muslim countries (Yusof, n.d., Towsend, 2006). Third, Western discrimination against the Muslim community (Twenge, 2001: 1058-1069) and fourth, external funding support. These four aspects have spawned natural spontaneous reaction among some Muslims to oppose the 'tyranny' (Maszlee, 2016). On the basis of a strong Islamic brotherhood, some Muslims have chosen to use the path of violence to respond to the tyranny (Awan, 2007: 2-21). Levesque (2011) further explains, all the continuing injustices of the Western world have given rise to a sense of threat, hence the hatred and anger create violent response among Muslims. Self-threads or feeling threatened makes one easy to get attached to terrorism.

The political issues mentioned have proven to directly affect Muslim individuals including the Malaysian women to engage with groups considered to be true religious fighters although they are regarded as extreme by the Muslims at large. This is in line with the findings from the interview which found that one of the main reasons that has influenced the involvement of individuals in the extremism group was because of the political influence particularly towards the tyrants as reported in turbulent countries. Their nature of sympathy has been exploited by the extremist groups for the sake of their struggle through particular modus operandi.

\section{Community/ Society}

There are two societal aspects which contributed to the reason of women choosing to involve in the extremist groups. First, a broken family system. As a result of a family system that does not work well, some of the women were also involved with social problems (Haras, 2004). Finally, when they realized and became conscious of what they have done, they tried to find a way to repent. This is when they were exposed to the propagation of the religious extremist group. Secondly, the attitude of the people who ignored of the involvement of a woman in the activities of religious extremism. By ignoring and underestimating women's involvement in extremist groups, the statistics of the 
Malaysian women's participation in the Daesh group keeps on increasing each year and the mode of violence is seen to be more extreme (Razak, 2018).

\section{Social Media}

Technological advancement today has led to the spreading of false elements, particularly from religious extremism groups, to be more complex and difficult to withstand. Globalization or the borderless world has led towards rapid development of extremism (Hassan, 2016). In the past, the media had less role to play, however, nowadays the social media and apps such as Youtube, Facebook, Twitter, Whassapp, blogs and so on have played an important role in the dissemination of ideology relating to extremist groups (Hassan, 2016). The researchers of extremism have come to mutual agreement that the extremist groups have managed to use social media successfully to gain support and recruit new members especially among IT-literate young people (Hizam \& Zamihan, 2016). The finding of this research has also shown the same result that the social media has played an important role in spreading ideology and recruiting new members of the Daesh group among Malaysian women. As referred to the interview finding, involving the reality of Malaysian women's involvement in the Daesh group, the PDRM acknowledged that they were recruited and operated through social media, in contrast to the previous militant groups like Jemaah Islamiah (JI) (Khan, 2018).

\section{Marriage}

Unlike other factors which are identical for the involvement of both men and women, marriage seems to be the only factor which has greatly influenced the decision of women to join the Daesh group. Most of the facts regarding to the involvement of women in the Daesh group, these women, either from the west or the locals, have desired or have become the wife to the Daesh fighters (Saltman, 2016). However, this matter is not a surprising issue as the Daesh men themselves need women's support as wives, thus the mothers of future members of the group (Strommen, 2017). These are the reasons of why women are willing to become the wives to the fighters even though they have to embrace higher risks in the future.

This study, from the analysis of the literature review and the interviews, found that marriage has become a key driver of women's decision to join the Daesh group. The reasons are as follow:

i. The original status as the wife of the Daesh warrior. As far as the study is concerned, the involvement of Malaysian women in Syria is 12 and all are believed to be the wife of the Daesh fighter (PDRM, 2018).

ii. The love stories between a woman and a member of the Daesh group. The example is the Ummi Kalsom Bahak's case reportedly planning to marry Aqief Huessin who was the Daesh fighter. Similar cases such as Shams and Siti Noor Aishah, Syamimi Faiqah Sulaiman who also wanted to do the same for their love.

iii. Influenced by the social media propaganda that offers a wonderful life in the 'Islamic State' of the Daesh group, including being the wife of handsome and attractive fighters. 
iv. Influenced by the extremism reading materials, for example in the case of Siti Noor Aishah Atam who was sentenced to five years in prison, after being found guilty of having 12 books on terrorist groups.

v. Offer to benefit benevolence. The PDRM explained:

"He promised everything, she went there to get married, with allowances, home, a car, wifi, salary, a handsome husband, all there, in a package. Of course people won't refuse to go there. When a person is somehow unwise, imprudent, that person will go." (Khan, 2018).

\section{Conclusion}

It can be concluded that the factors of involvement of women in the Daesh group are derived from the internal and external factors. Consistent findings show that women are so influenced by their surrounding as well as the internal problems which finally lead them to join and continue to stay with the Daesh group. Obviously, women have been used by the Daesh group for their political interests, thus changing the future regarding the safety of women involved. Hence, early stages of prevention should be taken so that women are not constantly exploited in the name of religion. The findings of this study are expected to help authorities and future researchers understand the causes and factors of Malaysian women's involvement and then take right action on the matter.

\section{References}

Ali, M. R. (2015). ISIS and Propaganda: How ISIS Exploits Women. Reuters Institute for the Study of Journalism, University of Oxford.

Archetti, C. (2014). Terrorism, Communication and The Media. Terrorism and Political Violence, ed. C. Kennedy-Pipe, G.Cubb dan S. Mabon. London: Sage.

Awan, A. N. (2007). Virtual Jihadist Media: Function, Legitimacy and Radicalizing Efficacy. European Journal of Cultural Studies, 10, 2-21.

Bakker, E. (2006). Jihadi Terrorists in Europe: Their Characteristics and the Circumstances in Which They Joined the Jihad: An Exploratory Study. Netherland: Netherlands Institute of International Relations.

Beutal, A. J. (2007). Radicalization and Homegrown Terrorism in Western Muslim Comunities: Lessons Learned for America. USA: Minarete of Freedom Institute.

Dunn, K. M. (2011). Challenging Racism: The Anti-Racism Research Project. University of Western Sydney, Australia.

Hassan, A. S. A. (2016). Daesh: Kebangkitan dan Pengaruh Media Sosial. Jurnal Komunikasi, 32, 381-404.

Hizam, H. \& Zamihan, M. Z. (2016). Bahaya ISIS (DAESH). Bangi: al-Himma Enterprise.

Kabir, N. A. (2007). Muslims in Australia: The Double Edge of Terrorism. Journal of Ethnic and Migration Studies, 33, 1277-1297.

Kamali, M. H. (2015). Extremism, Terrorism and Islam: Historical and Contemporary Perspectives. Islam and Civilisational Renewal (ICR), 6, 150-151.

Kneip, K. (2016). Female Jihad - Women in the ISIS. POLITICON the IAPSS Acedemic Journal, 29 (89), 88-106.

Levesque, R. J. R. (2011). Exstremism. DIm. Ensyclopedia of Adolescence. Levesque, R.J.R. (ed.). New York: Springer.

Maszlee, M. (2016). Siapakah ISIS?. ISIS. Batu Caves: PTS Publishing House. 
McCauley, C. (2012). Testing Theories of Radicalization in Polls of U.S. Muslims. Analyses of Social Issues and Public Policy, 12, 296-311.

McPherson, M., Smith-Lovin, L., \& Cook, J. M. (2001). Birds of a Feather: Homophily in Social Networks. Annual Review of Sociolog, 27, 415-444.

Merriem, S. B. (2002). Introduction to Qualitative Research. San Francisco: Jossey-Bass.

Patton, M. Q. (1990). Qualitative Evaluation and Research Methods. London: Sage Publications.

Piaw, C. Y. (2011). Kaedah Penyelidikan, ed. 2. Kuala Lumpur: Mc Gram Hill.

Rafiq, H. \& Malik, N. (2015). Caliphettes: Women and the Appeal of Islamic State. Quilliam Foundation.

Rahimullah. (2013). Understanding Violent Radicalization Amongst Muslims: A Review of the Literature. Journal of Psychology and Behavioral Science, 1 (1), 21-23.

Razak, M. I. A. (2018). Isu-isu Wanita dalam Fiqh Jihad Kumpulan Ekstremisme Agama: Kajian Terhadap Majalah Dabiq dan Kaitannya di Malaysia. Tesis PhD. Akademi Pengajian Islam, Universiti Malaya, Kuala Lumpur.

Sapurto, M. E. (2016). Probabilitas Teroris Perempuan di Indonesia. Jurnal IImu Sosial dan Ilmu Politik, 14, 211-228.

Stevens, T. \& Neumann, P. R. (2009). Countering Online Radicalisation. A Strategy for Action. London: The International Centre for the Study of Radicalisation and Political Violence (ICSR).

Townsend, M. (2006). Official: Iraq War Led to July Bombings. The Observer, http://observer.guardian.co.uk/uk_news/story/0,,1745085,00.html.

Veldhuis, T., \& Staun, J. (2009). Islamist Radicalisation: A Root Cause Model. Netherland: Netherlands Institute of International Relations Clingendael.

Weimann, G. (2016). Why Do Terrorist Migrate to Social Media?. DIm. Violent Extremism Online: New Perspective on Terrorism and the Internet. Ed. Aly, A., Macdonald, S. Jarvis, L. \& Chen. London: Routledge. 